\title{
Çok kısa hikâye kavramı ile Kur'an kıssaları ve nevadir arasındaki benzerlik ve farklılıklar
}

\section{Orhan OĞUZ1}

\begin{abstract}
APA: Oğuz, O. (2019). Çok kısa hikâye kavramı ile kuran kıssaları ve nevadir arasındaki benzerlik ve farklılıklar. RumeliDE Dil ve Edebiyat Araştırmaları Dergisi, (14), 494-504. DOI: 10.2900o/rumelide.541088
\end{abstract}

$\ddot{\mathbf{O z}}$

Bilim, sanat, dil ve edebiyat insanlığın ortak birikimleridir. Hiçbir bilimsel icat, bir ülkede kendiliğinden ortaya çıkmaz. Bunun mutlaka diğer ülkeler ve diğer milletlerle bir bağlantısı vardır. Günümüzde batıda ortaya çıkan bir icadın, doğuda buna ait basit bir örneği veya fikri vardır. Sanat, dil ve edebiyat da aynı şekildedir. Her millet diğerlerinin dilinden kelime alır. Diğer millete kelime verir. Batı edebiyatı doğu edebiyatından yüzyıllar boyu etkilenmiştir. Aynı şekilde batı edebiyatının da doğu edebiyatında etkileri vardır. Çok kısa hikaye batıda ortaya çıkmış bir kavramdır. Bu edebi tür Arap Edebiyatı'nda da kısa sürede yayılmıştır. Bu türle ilgili eserler yazılmış, araştırmalar yapılmıştır. Günümüzde bazı edebiyatçılar çok kısa hikaye ile bazı Arap edebiyatı ürünleri arasında benzerlikler kurmaktadırlar. Bu araştırmada çok kısa hikaye türü ile ilişkilendirilen Kur'an kıssaları ve nevadir incelenmiştir. Kur'an-ı Kerim’in Arap dil ve edebiyatında önemli bir yeri vardır. Arap dilinin kaynaklarından biridir. Ayrıca üstün bir edebi anlatım tarzı vardır. Kıssa özellikle Kur'an-ı Kerim’in ortaya koyduğu bir kavramdır. Yaşanmış olayların anlatılmasına kıssa denir. Eş anlamlısı hikayedir. $\mathrm{Bu}$ da hem yaşanmış hem hayal ürünü anlatımdır. Nevadir ise Arap edebiyatındaki nükteli hikayelerdir. Araştırma üç bölümden oluşmaktadır. Giriş bölümünde kıssa ve nevadir kelimeleri açıklanmıştır. İkinci bölümde Kur'an kıssaları ve nevadir ile çok kısa hikaye arasındaki benzerlikler ve farklılıklar incelenmiştir. Sonuç bölümünde ise bu araştırmadan çıkan bulgular ortaya konmuştur.

Anahtar kelimeler: Bilim, sanat, kıssa, çok kısa hikaye, hikaye.

\section{The similarity and differences between the rises of very short story and the ruins of the Qur'an}

\begin{abstract}
Science, art, language and literature are the common accumulations of humanity. No scientific inventions occur spontaneously in a country. It has a connection surely with other countries and other nations. Now, there is an example of the invention that appeared in the west example or idea in the east. Art, language and literature are likewise. Every nation get words from others language and give words to the others nations. West literature effect from east literature centuries. Likewise, there are effects of west literature over east literature. The very short story is a concept that come up in the west. This type literary spread in short time in Arabic literature. About this type, literature books written and studies research. Today, some of the writers of literature have similarities with many short stories and some Arabic literature products. In this study, it was examined Quran stories and jokes associated with very short stories. The Holy Quran has a very important place in Arabic language and literature. It is one of the sources of Arabic language. In addition, it has a superior

1 Dr. Öğr. Üyesi, Karamanoğlu Mehmetbey Üniversitesi, Edebiyat Fakültesi, Mütercim Tercümanlık Bölümü, (Karaman, Türkiye), arapcadersi@hotmail.com, ORCID ID: 00oo-0001-5467-3671 [Makale kayit tarihi: 30.01.2019-kabul tarihi: 14.03.2019; DOI: 10.29000/rumelide.541088]




\begin{abstract}
literary style. Kussa is a concept that the Holy Quran laid out it. Explaining of experienced events called kıssa. It synonym is story. This is an expression for experienced events and figment. Nevadir is witty stories in Arabic literature. The research consists of three parts. In the introduction section, the words of the short and nevadir are explained. In the second chapter, the similarities and differences between Qur'anic parables and the story and the story are examined. In the conclusion section, the findings of this research are presented.
\end{abstract}

Key words: Science, art, kıssa, very short story, story.

\title{
Giriş
}

Çok kısa hikaye 20. Yüzyılda very short story adıyla batıda ortaya çıkan bir kavramdır. Bu kavramı ilk kez 1925 yılında Amerikalı Hikâye yazarı Emest Miller Hemingway (ö. 1961) edebiyat dünyasına kazandırmıştır (Şavuş, 2018: 364). Temel özelliği kısa ve verilmek istenen mesaja odaklı olması ile ön plana çıan çok kısa hikaye قصة قصيرة جدا şی bir şekilde yayılmıştır. Arap edebiyatçıları bu alanda eserler vermiş, akademisyenler üzerinde akademik çalışmalar yapmışlardır. Bu edebi türün kısa ve geniş anlamlar içeren cümlelerden oluşması, edebi ürünlerin sunulduğu internet sitelerinin çok kısa hikâyelere daha geniş vermesini sağlamış bu da kısa bir süre içerisinde geniş bir alana yayılmasında etkili olmuştur (el-Batayine, 2011: 222). Fakat hiçbir edebi tür, hatta hiçbir icat bir temele dayanmadan birden ortaya çıkmamaktadır. Nasıl ki günümüzde, batıda çıkan icatlarda doğunun etkisi varsa, batı edebiyatında da doğu etkisinin olması kaçınılmazdır. $\mathrm{Bu}$ günkü medeniyet batı medeniyeti olarak isimlendirilmektedir. Fakat batıllar bu ilerlemeleri yoktan var etmemişlerdir. Başka medeniyetlerin ürettikleri ürünler üzerine yeni gelişmeler kaydetmişlerdir (Akyol, 2006, s. 118). Çünkü toplumlar her zaman diğerlerinden etkilenmekte, başka toplumun kültürünü, inançlarını, adetlerini, dillerinden kelimeleri, edebi ürünlerini almakta zaman içerisinde kendi dil ve kültürüne katmaktadır. Dolayısıyla bu edebi türün de mutlaka bir temeli vardır. Uzun yıllar içerisinde birçok milletin edebi özelliklerinden etkilenerek günümüze gelmiştir.

Aynı kavram çerçevesinde Arap edebiyatında da benzer ürünlerin olduğu dile getirilmekte ve bununla paralel olarak çok kısa anlatımlar örnek olarak verilmektedir. Bu örneklerin başında da Kur'an kıssaları gelmektedir. Ayrıca Arap edebiyatında الخطبة hutbe, قصص الحيوان hayvan hikayeleri, fikralar النوادر ve gibi nesir türlerinin de çok kısa hikaye ile aynı özellikler gösterdiği iddia edilmektedir (Merami \& Arabi, 1390 h: 102). Biz bu araştırmamızda bunların içerisinden Kur'an-ı Kerim kıssaları ve Arap edebiyatındaki nevadir konusunu inceledik. Benzerliklerin olup olmadı̆̆ını ortaya koymaya çalıştık.

Bilindiği gibi Kur’an-ı Kerim sadece dünya hayatını düzenleyen, Ahiret hayatı ilgili bilgiler veren bir kanun kitabı değildir. İçerisinde dünya hayatını düzenleyen kurallar olduğu gibi, ibadet esasları ile ilgili emir ve bilgiler, ahlak esasları, peygamber kıssaları vb. konular da bulunmaktadır. Kur'an-ı Kerim'in araştırmamızı ilgilendiren yönü ise edebi bir kitap olmasıdır. Kur’an-ı Kerim edebi özelliği ile geldiği toplum üzerinde edebi açıdan da etkili olmuştur. Bu etkiyi anlayabilmek için Kur'an-ı Kerim’in inmeden önceki toplum hayatına bir göz atmak faydalı olacaktır.

Cahiliye dönemi olarak adlandırdığımız İslam'ın gelişinden önceki dönemin en önemli özelliği edebiyatın zirvede olduğu bir zaman olmasıdır. Bu dönemde özellikle şiir ve şairler ön plana çıkmıştır. Genelde sözlü edebiyatın hakim olduğu bu dönemde şair olmak bir kişi için çok önemli bir prestij kaynağıdır. Kabileler halinde yaşayan toplumda bir kabile içinden şairin çıkması da o kabile için gurur 
vesilesidir. Şair şiirleriyle istediği kişiyi toplum nazarında yüceltebilir, sevmediği kişiyi kötüleyerek konumunu düşürebilirdi (Demirayak, 2012: 72).

Şiir belli kurallarla belli vezinlerle söylenirdi. Ayrıca şiirde belli bir konu sıralaması vardı. Şair şiirine sevdiği kişinin daha önce kaldığı fakat terk ettiği yerin kalıntılarına uğraması ile başlardı. Çünkü daha çok göçebe bir hayat yaşandığı için bir bölgede konaklanır. Daha sonra çadırlar sökülür başka bir bölgeye göçülürdü. Şair de sevdiğinin bu yerdeki hatıralarını özlemle dile getirerek şiirine başlardı. Daha sonra tabiat ve hayvan tasvirleri, şairin kahramanlıkları, sevdiğinin özellikleri gibi konular şiirde yerini alırdı (Demirayak, 2012: 114).

Kur'an-ı Kerim geldiğinde farklı bir anlatım tarzı getirmiştir. Ondaki anlatım tarzı ne şiir ne de nesirdir. İkisi arasındadır. Ayet sonlarında kafiye vardır. Ama ayet uzunlukları birbirinden farklıdır. Ayrıca Kur'an-ı Kerim'in Arap şairlerini hayrete düşüren bir anlatım tarzı vardır. Buna Kur’an-ı Kerim'in icazı denilmektedir.

İcaz kelimesi aciz olmak, gücü yetmemek anlamındaki عز kökünden gelen ve aciz birakmak anlamındaki اعجز fiilinin mastarıdır (ez-Zebidi, tsz: 15/211). Aciz bırakan anlamındaki معزة Mucize kelimesi de yine aynı kökten gelmektedir (Ebu'l-Beka, tsz: 149). Kur'an-ı Kerim’in konu olarak dikkati çeken kısımlarından birisi de bu araştırmada yer verdiğimiz kıssalardır.

Kur'an-ı Kerim'de peygamber kıssaları ve geçmiş kavimlerle ilgili kıssalar çok önemli bir yer tutmaktadır. Kıssa kelimesi "anlattı" anlamına gelen قص fiilinden türemiştir (İbn Dureyd, 1987: 1/142). Eş anlamlısı حكاية "hikaye" dir. O da حكى kökünden gelmektedir (er-Razi, 1999: 78). Fakat aralarında şöyle bir fark vardır. Kıssa gerçek olaylardır. Kur'an-ı Kerim'de bu yüzden hikaye kavramı kullanılmamıştır. Fakat hikaye olmuş veya olabilecek bir olayın anlatılmasıdır (Şengül, 2002: 498). Ayrıca Kur’an kıssalarını sadece edebi bir tür olarak görmek doğru değildir. Kur'an kıssalarını Kur’an-ı Kerim’in indiriliş gayesinden ayrı düşünmek mümkün değildir. Kur'an kıssalarının da tıpkı Kur’an-ı Kerim'in diğer ayetlerinde olduğu gibi ilahi bir vahiy olduğunun altını çizmek gereklidir (Abbas, 2010: 43). Arap edebiyatında hikaye kavramı da olmasına rağmen kıssa kavramı daha yaygın kullanıma sahiptir. Bunda Kur'an-ı Kerim'de kıssa kavramının kullanılmasının etkisi inkâr edilemez. Ama bu kavramın Kur'an-ı Kerim dışındaki kullanımı hem olmuş hem de olabilecek olaylar içindir.

Çok kısa hikaye kavramına ait örneklerin eski Arap Edebiyatı'nda bulunduğu iddia edilen Nevadir Arap edebiyatının önemli ürünlerindendir. نو ادر nevadir kelimesi نادرة kelimesinin çoğuludur. Türkçeye fikra olarak tercüme edebileceğimiz bu kelime "Garip, olağanın dışında ifadeler." (ez-Zemahşeri, 1998: 2/259) şeklinde tarif edilmiştir. Arap edebiyatında fikra türüne daha başka da isimler verilmiştir. Bunlar

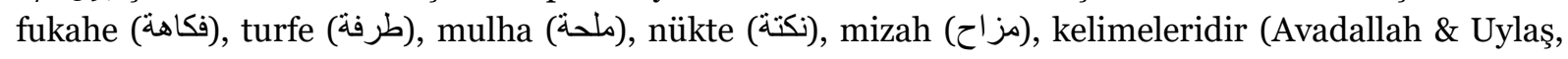
2010: 152). Biz bu araştırmada Nevadir kavramını kullanacağız. Nevadir türü eserlerin yazılmaya başlanması hicri 2. Yüzyılda başlamış 3. Yüzyılın ortalarına kadar devam etmiştir. Bu eserlerin yazılma sebebi, Arapçada az kullanılan ve anlamı iyi bilinmeyen kelimelerin ortaya çıkarılması ve kullanımı olmuştur. Örnek olarak Ebu Zeyd el-Ensari'nin Kitabu'n-Nevadir fi'l-Luga adlı kitabında, yöntem olarak önce az kullanılan ve anlamı iyi bilinmeyen kelimelerin geçtiği şiirler yazılmış, sonra orada geçen kelimeler açıklanmıştır. Ebu Ali el-Kali'nin en-Nevadir adlı eseri ise fikra tarzı haber, hikaye ve şiir türlerini içerisinde barındırmakta ve bunlarda geçen az kullanılan ve anlamı iyi bilinmeyen kelimeleri açıllamaktadır (Durmuş, 2007: 29). 


\title{
Kur'an kıssaları ve nevadir ile çok kısa hikaye arasında benzer unsurlar
}

Çok kısa hikaye türünün geçmişte Kur'an kıssalarından bazılarında ve nevadir türü eserlerde de olduğu fikri ortaya konulduğu giriş kısmında belirtilmişti. Buna dayanak olarak Kur'an kıssaları incelenmiş ve bazılarının kıssa, bazılarının da çok kısa hikaye türüne gireceği iddia edilmiştir (Merami \& Arabi, 1390 h: 103). Bu iddia temellendirilirken Kur’an kıssaları ile çok kısa hikayenin unsurları karşılaştırılmıştır. Ayrıca bu araştırmada buna ek olarak nevadir türünden de örnekler verilerek benzerlikleri ve farklılıkları ortaya konulacaktır.

\section{Kişi}

Çok kısa hikayelerde kişi asıl unsur değildir. Hikayede anlatılmak istenen şey bir kişinin hayatı değildir. Kişi sayısı bir iki kişi ile sınırlıdır. Bazen açıcça zikredilir. Bazense hiç kişi ismi geçmez. Önemli olan verilmek istenen mesajdır.

Kişi Kur'an kıssalarının en önemli unsurudur. Kıssanın veya kıssada anlatılan olayların eksenini oluşturur (Merami \& Arabi, 1390 h: 106). Şahıs genellikle açıkça belirtilir. Kur'an-ı Kerim'de yirmi yedi peygamber geçmektedir. Ana karakter ya bu peygamberlerden biri olur. Veya Allah tarafindan sevilen bir kul olur. Kıssalarda kişi sayısı çoktur. Musa'nın (as) kıssalarında kardeşi Harun, mücadele ettiği Firavun, buzağı yapıp insanları taptıran Samiri, gibi.

Ama çok hikaye türüne girdiği söylenen Kur'an kıssalarında olay bir iki kişi etrafında döner. Asıl anlatılmak istenen kişiler değil olaydır. Kişinin az olması, bazen de hiç isim zikredilmemesi bu gruptaki Kur’an kıssalarının çok kısa hikaye ile benzerliği sonucuna ulaştırmıştır. Çok kısa hikayelerde de kişi ön planda değil olay ön plandadır (Merami \& Arabi, 1390 h: 107).

Bu konuya Yasin Suresi 20. Ayetle başlayıp 27. Ayete kadar devam eden bir kişinin başından geçenler çok kısa hikâyeye örnek olarak gösterilmektedir (Merami \& Arabi, 1390 h: 106). Söz konusu kıssa şu şekildedir:

\begin{abstract}
Sehrin öbür ucundan bir adam koşarak geldi ve şöyle dedi: "Ey kavmim! Bu elçilere uyun." (20) "Sizden hiçbir ücret istemeyen kimselere uyun, onlar hidayete erdirilmiş kimselerdir." (21) "Hem ben, ne diye beni yaratana kulluk etmeyeyim. Oysa siz de yalnızca ona döndürüleceksiniz." (22) "Onu bırakıp da başka ilahlar mı edineyim? Ĕger Rahmân bana bir zarar vermek istese, onların șefaati bana hiçbir fayda sağlamaz ve beni kurtaramazlar." (23) "O takdirde ben mutlaka açık bir sapıklık içinde olurum." (24) "Şüphesiz ben sizin Rabbinize inandım. Gelin, beni dinleyin!" (25) (Kavmi onu öldürdüğünde kendisine): "Cennete gir!" denildi. O da, "Keşke kavmim, Rabbimin beni bağışladığını ve beni ikram edilenlerden kıldığını bilseydi!" dedi. (26-27)
\end{abstract}

Burada araştırmacıların belirttiği gibi kişi ve yer ismi belirtilmemiştir. Olay bir konu etrafında dönmektedir. Vurgulu bir girişi vardır. Fakat bu kıssa Yasin Suresi 13. Ayetten itibaren başlayan Peygamberler ve kavimlerin mücadelesinin devamıdır. Müstakil bir kıssa değildir. Çok kısa hikayenin kısa olması, tek bir konuya yönelik olması kurallarına uymaz. Dolayısıyla bu kıssanın çok kısa hikaye özelliğini gösterdiğini iddia etmek doğru bir yaklaşım olmayacaktır.

Fakat Kur'an-ı Kerim'deki başka bir kıssa, çok kısa hikayenin yukarıda anlatılan özelliklerine benzerlikler taşımaktadır. Bakara suresi 258. Ayetteki kıssa şu şekildedir:

Allah, kendisine hükümdarlık verdi diye (șımarıp böbürlenerek) Rabbi hakkında İbrahim ile tartıșanı görmedin mi? Hani İbrahim, "Benim Rabbim diriltir, öldürür." demiş; o da, "Ben de diriltir, 
öldürürüm" demişti. (Bunun üzerine) İbrahim, "Şüphesiz Allah güneşi doğudan getirir, sen de onu batıdan getir" deyince, kâfir şaşırıp kaldı. Zaten Allah zalimler topluluğunu hidayete erdirmez. (258)

Kıssada iki şahıs bulunmaktadır. Bunlardan birisi bilinen bir şahsiyettir. Diğeri ise hem bilinmemektedir hem de ismi zikredilmemektedir. Kıssada zaman ve mekan belirtilmemiştir. Şahıslar hakkında ayrıntılar ve betimlemeler yoktur. Olay örgüsü yaratıcının kudreti üzerine gelişmektedir. Ayetin öncesi ve sonrası incelendiğinde başka bir kıssa ile bağlantısı bulunmamaktadır. Dolayısıyla kısa olması, belli bir konuya odaklanması, sadece bir konudan bahsedilmesi, ayrıntılara girilmemesi gibi hususlar bu kıssanın, çok kısa hikaye ile benzer özellikler taşıdığını göstermektedir.

Aynı benzerlik nevadir türünün bazılarında da görülmektedir.

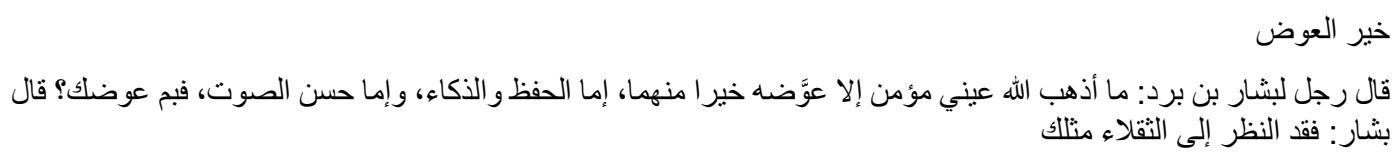

Bedelin Hayırlısı

Bir adam Beşşar b. Burd’e dedi ki: Allah bir müminin iki gözünü onlardan daha iyisi karşılığında değiştirmeden almaz. Bunlar ya ezber kuvveti ve zeka ya da güzel ses. Peki sana ne bedel verdi?

Beşşar şöyle cevap verdi: Senin gibi can sıkıcı kişileri görmemek (Muhammed, tsz: 13).

Burada bir isim vardır o da Beşşar b. Bürd. Konuştuğu kimsenin ismi verilmemiştir. Yer ve zaman da zikredilmemiştir. Olay iki satırla kısaca anlatılmıştır ve tek bir olaydan bahsedilmektedir.

\section{Olay örgüsü}

Çok kısa hikayelerde olay örgüsü bir iki kişi arasında bir mücadele ile başlayabilir. Muhammed Said erRayhani’nin yazdığı غذاء الأمل "Umudun Gıdası" adlı çok kısa hikayede bu durum görülmektedir.

$$
\begin{aligned}
& \text { غذاء الأمل } \\
& \text { - معالي السيد الرئيس، الفيضان سيمسح الوجود الإنساني في هذه المدينة المنكوبة! } \\
& \text { - ستأتينا المساعدات الإنسانية قريبا. } \\
& \text { - معالي السيد الرئيس، ولكن الناس لن يستطيعوا الانتظار في الماء. سيموتون حتما! } \\
& \text { يقينا، لا. الناس هنا هم أبناء النهر. إنهم يجيدون السباحة. }
\end{aligned}
$$

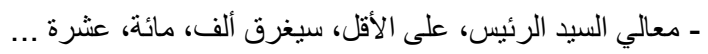

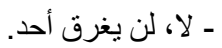

$$
\begin{aligned}
& \text { - و أنتم، معالي السيد الرئيس، هل تجيدون الدئ السباحة، أسوة بمواطنيكم؟! }
\end{aligned}
$$

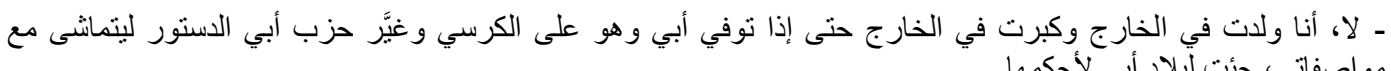

$$
\begin{aligned}
& \text { مو اصفاتي، جئت لُبلاد أبي لأحكمها. } \\
& \text { - معالي السيد الرئيس، قد يكون من بين هؤ لاء الناس الذي جرفهم الفيضان، من ولد بالخارج، مثلك. }
\end{aligned}
$$

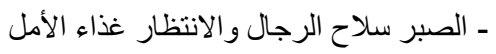

Umudun Gidası

- Sayın başkan ekselansları, sel bu çileli şehirde insaniyetin varlığına izin verecek.

- İnsani yardımlar yakında bize gelecek.

- Sayın başkan ekselansları, insanlar suyun içinde bekleyemezler. Mutlaka ölecekler.

- Kesinlikle, hayır. İnsanlar burada nehrin çocuklarıdır. Onlar yüzmeyi iyi bilirler. 
- Sayın başkan ekselansları, en azında, bin kişi boğulacak, yüz, on.

- Hayır, hiç kimse boğulmayacak.

- Ya siz. Sayın başkan ekselansları. Vatandaşlarınıza örnek olarak siz yüzmeyi iyi biliyor musunuz?

- Hayır. Ben yurt dışında doğdum ve yurt dışında büyüdüm. Sonunda babam tahtta ölünce babamın partisi benim standartlarıma uyması için anayasayı değiştirdi. Çünkü ben babamın ülkesine ona hükmetmek için geldim.

- Sayın başkan ekselansları, bu insanlar içinde selin sürüklediği kişiler olabilir. Yurt dışında doğan bir kişi. Senin gibi.

- Sabır er kişilerin silahıdır. Beklemek umudun gıdasıdır (er-Rayhani, 2014: 65).

Bu hikayede bir ülkenin başkanı ile ona yakın olan bir kişi muhtemelen yardımcısı arasındaki konuşmalar yer almaktadır. Ülkede bir felaket vardır. Başkanın bu felaketin daha fazla büyümemesi ve can kaybı yaşanmaması için bir takım önlemle alması gerekmektedir. Fakat diğer kişinin tüm uyarılarına rağmen hiçbir şey yapmaz. Aksine kendisine yöneltilen uyarılara hep bir mazeret bulur.

Aynı durum, Kur’an kıssalarının çok kısa hikaye türüne giren kısmında da olduğu iddia edilmiştir. Olayda iki kişi vardır. Birisi hakkı temsil ederken diğeri batılı temsil etmektedir. İkisi arasında geçen mücadele olayın düğümüdür. Olay örgüsü bu düğümün çözülmesi etrafında yoğunlaşmıştır. Yukarıda örnek olarak verilen Hz. İbrahim ile ilahlık taslayan bir kafir arasında geçen olay bu benzerliğe örnek verilmiştir (Merami \& Arabi, 1390 h: 107).

Verilen başka bir örnekte kişinin kendi içindeki mücadelesi anlatılmaktadır. Burada olumsuz bir şahsiyet yoktur. Mücadele iki kutup arasında yaşanmaz. Buradaki kişi kendi içinde Allah’ın ölüleri nasıl dirilteceğini sorgulamaktadır. Bakara 259. Ayetteki kıssa şu şekildedir:

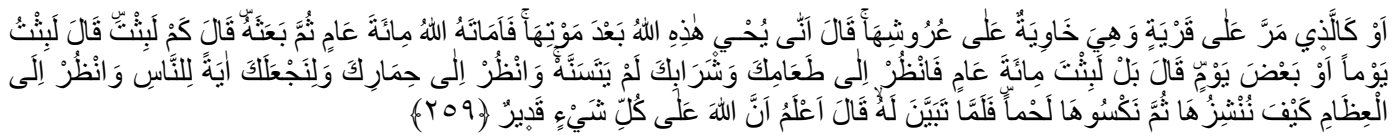

"Yahut altı üstüne gelmiș (ıpıssız duran) bir şehre uğrayan kimseyi görmedin mi? O, "Allah, burayı ölümünden sonra nasıl diriltecek (acaba)?" demişti. Bunun üzerine, Allah onu öldürüp yüzyll ölü bıraktı, sonra diriltti ve ona sordu: "Ne kadar (ölü) kaldın?" O, "Bir gün veya bir günden daha az kaldım" diye cevap verdi. Allah şöyle dedi: "Hayır, yüz sene kaldın. Böyle iken yiyeceğine ve içeceğine bak, henüz bozulmamış. Bir de eşeğine bak! (Böyle yapmamız) seni insanlara ibret belgesi kılmamız içindir. (Eşeğin) kemikler(in)e de bak, nasıl onları bir araya getiriyor, sonra onlara nasıl et giydiriyoruz?" Kendisine bütün bunlar apaçık belli olunca, şöyle dedi: "Şimdi, biliyorum ki; şüphesiz Allah'ın gücü her şeye hakkıyla yeter." (259)

Kıssada mekan ve zaman yoktur. Kıssanın öncesine ve sonrasına bakıldığında bir kıssanın devamı olmadığı görülmektedir. Olayın tek konu etrafında dönmesi, kısa olması, zaman-mekan bildirilmemesi, çok kısa hikaye özellikleriyle uyum göstermektedir.

\section{Zaman ve mekan}

Çok kısa hikayede sınırlı bir zaman ve sınırı bir mekan vardır. Bu sınırılık çok kısa hikayenin en önemli özelliğidir. Çok kısa hikayede vurgulanmak istenen mesaj önemlidir. Bu yüzden zaman ve mekan da buna göre ayarlanır. Ya hiç zaman ve mekandan bahsedilmez. Ya da kısa bir işaretle belirtilir. Bu durum şu çok kısa hikayede görülmektedir.

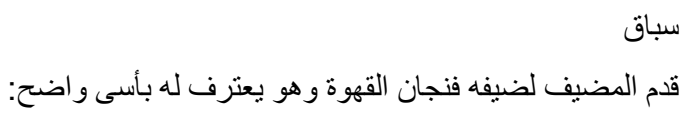




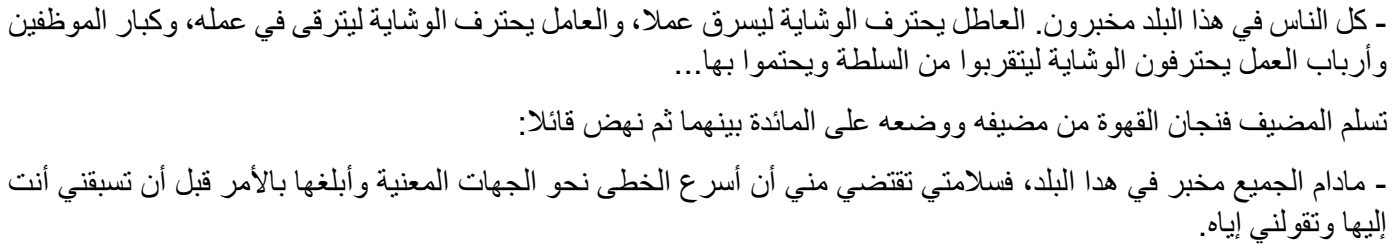

Yarış

Ev sahibi misafirine bir fincan kahve sundu. Büyük bir üzüntüyle itiraf ediyordu.

- Bu şehirdeki bütün insanlar casus. İşsiz, bir iş çalmak için gammazlamayı meslek edinmiş. İşçi işinde yükselmek için gammazlamayı meslek edinmiş. Büyük memurlar ve iş sahipleri hükümete yaklaşmak için gammazlamayı meslek edinmiş. Kendilerini onunla koruyorlar...

Misafir kahve fincanını ev sahibinden aldı. Sonra onu sofranın üzerine ikisinin arasına koydu. Sonra şöyle söyleyerek kalktı.

- Madem bu şehirde herkes casus benim kurtuluşum, beni geçip benim hakkımda yalan söz söylemeden önce, ilgili yerlere doğru hızla yürümemi ve onlara iși haber vermemi gerektiriyor (erRayhani, 2014: 44).

Hikayede herkesin birbirini gammazladığı bir toplumdan bahsedilmektedir. Olay bir evde geçmektedir. Fakat evin özelliklerinden bahsedilmemiştir. Ayrıca zaman da geçmemektedir. İnsanların birbirleri aleyhine sözler söyledikleri dönem hangi zamandır veya ev sahibi ve misafir günün hangi zamanında oturup konuşmuşlardır. Bunlarla ilgili hiçbir bilgi yoktur. Konu tamamen insanların yaptıkları davranışlarla ilgilidir.

Çok kısa hikayeye benzerliği vurgulanan Kur’an kıssalarında da bu husus kendini göstermektedir (Merami \& Arabi, 1390 h: 108). Hz. İbrahim ile ilahlık taslayan kişi nerede konuştular, ne zaman konuştular kıssada belirtilmemiştir. Burada önemli olan ilahlık iddiasının geçersizliği ve Hz. İbrahim’in bu görüşü nasıl çürüttüğüdür.

Aynı durum nevadir için de geçerlidir.

$$
\begin{aligned}
& \text { بيت بشبه القبر } \\
& \text { قال عثمان بن دراج الطفيلي: مرت بنا جنازة يوما، ومعي ابني، وفي الجنازة امر أة تبكي، وتقول: الآن يذهبون بك إلى بيت لا لإناء }
\end{aligned}
$$

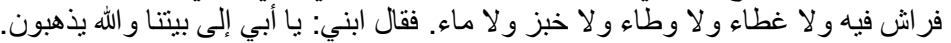

Kabre Benzeyen Ev

Osman b. Derrac et-Tufeyli şöyle dedi: Bir gün bir cenaze geldi. Yanımda da oğlum vardı. Cenazede bir kadın ağllyor ve şöyle söylüyordu. Şimdi seni bir eve götürecekler orada ne yatak var ne örtü var halı var he ekmek var ne su var. Oğlum dedi: Baba vallahi onu bizim eve götürüyorlar (Muhammed, tsz, s. 15).

$\mathrm{Bu}$ örnekte zaman ve mekan bildirilmemiştir. Osman b. Deccac et-Tufeyli, cimriliği ile bilinen bir kimsedir. Kıssada buna vurgu yapılmaktadır. Zaman ve mekan bildirilmemesi çok kısa hikaye özelliği göstermektedir.

\section{Olaya giriş}

Çok kısa hikayede anlatılacak olaya giriş anidir. Hikayedeki gibi önce yer ve şahıslar ayrıntıları ile anlatılarak olaya hazırlık yapılmaz. Bu durum bazı Kur'an kıssalarında da görülmektedir. Bazıları bir soru ile başlamaktadır (Merami \& Arabi, 1390 h: 109). Bakara suresi 258. Ayette İbrahim'le (as) mücadele eden adamı anlatmak için “İbrahim'le mücadele eden adamı görmedin mi?” sorusu kıssanın başlangıcıdır. Bu tür bir giriş okuyanı direkt olarak olayın içine itmektedir. 
Başka bir örnek de Bakara suresi 266. Ayetteki bahçe sahibi bir kimsenin kıssasına giriş için sorular "Sizden biriniz kendisinin bir bahçesinin olmasını arzu eder mi” sorusudur.

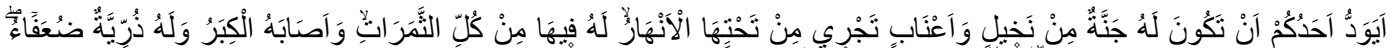

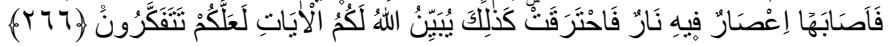

Herhangi biriniz ister mi ki, içerisinde her türlü meyveye sahip bulunduğu, içinden ırmaklar akan, hurma ve üzüm ağaçlarından oluşan bir bahçesi olsun; himayeye muhtaç çocukları var iken ihtiyarlık gelip kendisine çatsın; derken bağı ateşli (yıldırımlı) bir kasırga vursun da orası yanıversin? Allah düşünesiniz diye size âyetlerini böyle açılklyor. (266)

Kur’an kıssalarındaki başka bir ani giriş ifadeleri zaman ifade eden إذ لما vedatlarının kullanılmasıdır. Bunlara örnek olarak Bakara suresi 260. Ayette İbrahim (as) a ait olan kuşların diriltilmesi kıssasıdır.

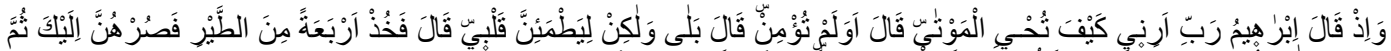

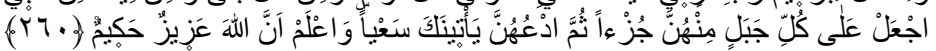

Hani İbrahim, "Rabbim! Bana ölüleri nasıl dirilttiğini göster" demişti. (Allah ona) "İnanmıyor musun?" deyince, "Hayır (inandım) ancak kalbimin tatmin olması için" demişti. "Öyleyse, dört kuş tut. Onları kendine alıştır. Sonra onları parçalayıp her bir parçasııı bir dağın üzerine bırak. Sonra da onları çağır. Sana uçarak gelirler. Bil ki, şüphesiz Allah mutlak güç sahibidir, hüküm ve hikmet sahibidir." (260)

و إذا بشر “Müjdelendiği zaman....” ifadesiyle başlamaktadır.

Onlardan biri, kzz ile müjdelendiği zaman içi öfke ile dolarak yüzü simsiyah kesilir! (58)

Kendisine verilen kötü müjde (!) yüzünden halktan gizlenir. Şimdi onu, aşağllanmış olarak yanında tutacak mı, yoksa toprağa mı gömecek? Bak, ne kötü hüküm veriyorlar! (59)

\section{Diyalog}

Çok kısa hikayede sıklıkla kullanılan bir tekniktir. Çok kısa hikayenin kısa olması ve verilmek istenen mesaja odaklı olması sebebiyle, diyalog çok kısa hikayenin vermek istediği mesaja çok uygundur (Merami \& Arabi, 1390 h: 111). Yukarıda örneğini verdiğimiz ülkesi sel felaketine uğrayan başkan ile onu can kaybına karşı uyaran kişi arasında geçen konuşmaların yer aldığı çok kısa hikayede sadece diyaloglar yer almaktadır.

Başka bir örnek de نحو المطار "Havaalanına Doğru” adlı hikâyedir.

$$
\begin{aligned}
& \text { نحو المطار } \\
& \text { فاجأ الحاجب سيادة الرئيس و هو يقر أرواية "نحو المنار" قائلا: } \\
& \text { ـ ـ معالي السيد الرئيس، الثُبب يحرق نفسه في الخارج فرادى وجماعات احتجاجا على الحرمان من الحرية! } \\
& \text { ـ معالي السيد الرئي، الثعب أوقف حرق نفسه ويهدد بحرق ذويك كما احترق ذوو هم! } \\
& \text { ـ ـ معالي السيد الرئيس، الثعب أوقف حرق نفسه ويهدد بحرقاك لإطفاء الغضب الثعبي المنعاظم! }
\end{aligned}
$$

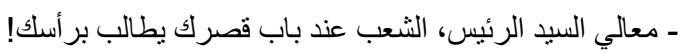

$$
\begin{aligned}
& \text { ـ معالي السيد الرئيس، الثنعب يهزّ باب القصر استعدادا لاقتحامه! }
\end{aligned}
$$

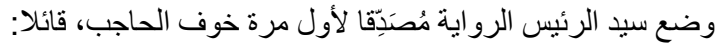

$$
\begin{aligned}
& \text { ـ ألا تسيطرون على الوضع؟ } \\
& \text { - لا أحد يسيطر على الوضع، معالي السيد الرئيس! }
\end{aligned}
$$




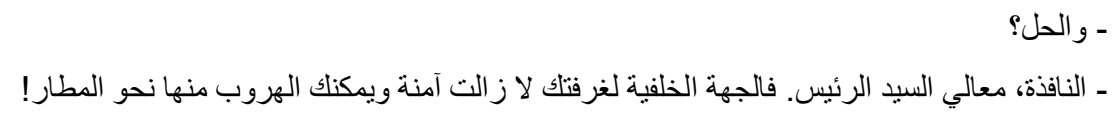

Havaalanına doğru

Muhafız, "Nahve’l- Menar" (Deniz Fenerine Doğru) romanını okuyan saygıdeğer reisle aniden karşılaştı ve şöyle dedi:

- Sayın başkan ekselansları, halk kendi kendini dışarda tek tek ve toplu olarak, hürriyetin kısıtlanmasından dolayı protesto etmek için kendini yakıyor.

- Sayın başkan ekselansları, halk kendini yakmayı bıraktı. Senin sahiplerini yakmakla tehdit ediyorlar. Tıpkı kendi sahiplerinin yıkıldı $\breve{1}$ gibi.

- Sayın başkan ekselansları, halk kendini yakmayı bıraktı. Halkın büyüyen kızgınlı̆̆ını söndürmek için seni yakmakla tehdit ediyorlar.

- Sayın başkan ekselansları, halk sarayının kapısında. Senin başını istiyor.

- Sayın başkan ekselansları, halk, içeri akın etmeye hazırlandı sarayının kapısını yıkıyor.

Başkan, ilk kez muhafızın korkusunu doğrulayarak, romanı koydu. Ve dedi:

- Duruma hakim olamiyorlar mı?

- duruma hakim olacak kimse yok. Sayın başkan ekselansları.

- Çözüm?

- Pencere, başkan ekselansları. Odanın arka kısmı hala emin. Oradan havaalanına doğru kaçabilirsin (er-Rayhani, 2014: 56).

Bu hikayede ana karakter muhafizdır. Halk yönetimi protesto etmekte ve kısıtlanan hürriyetlerini istemektedirler. Fakat başkan olaylara karşı umursamaz bir tavırdadır. Oturmuş rahatça roman okumaktadır. Olay ikisi arasındaki diyaloğa dayanır. Korumanın çok konuşmasına rağmen başkanın konuşması azdır. Bu da başkanın olaylara karşı ilgisizliğini vurgulamaktadır.

Bu durum Kur'an kıssalarında da kendini göstermektedir. Yukarıda zikredilen İbrahim (as) ın ilahlık iddia eden kimseyle diyaloğu, bahçe sahiplerinin konuşmaları örnek olarak verilebilir.

Aynı şekil nevadirde de görülmektedir. أنت الحسن "Sen Güzelliksin” başlıklı hikayede olay bir diyalogla anlatılmaktadır.

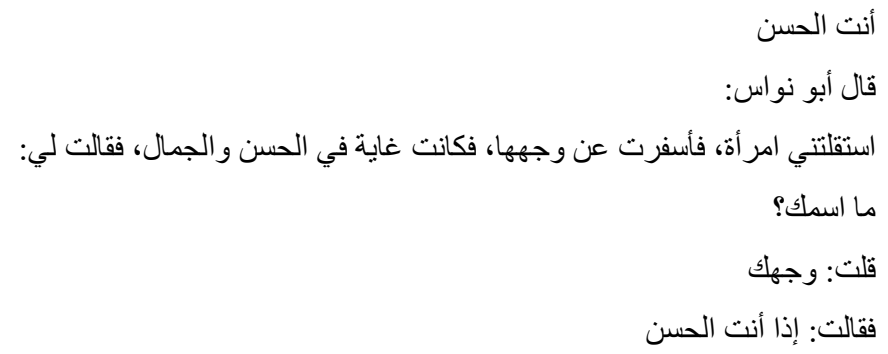

Sen Güzelliksin

Ebu Nuvvas dedi: Beni bir kadın karşıladı. Yüzünü açtı. Çok güzeldi. Bana dedi:

Adın ne?

Dedin: Senin yüzün

Dedi: o halde sen güzelliksin (Akil, 1999, s. 12) 
Burada iki kişi arasında geçen olay anlatılmaktadır. Nevadirde genelde takip edilen usule göre meşhur bir kişi ile ismi geçmeyen bir kişi arasında geçen olay anlatılır. Burada da olay Ebu Nuvvas ve bir kadın arasında geçmektedir. Yer ve zaman yoktur. Olay örgüsü sadece kadının güzelliği etrafında dönmektedir.

\section{Kur'an kıssaları ve nevadir ile çok kısa hikayeler arasındaki farklar}

Yukarıda Kur'an Kıssaları ve nevadir ile çok kısa hikayeler arasındaki ortak noktalara değinildi. Fakat bu ortak noktalar yanında birtakım farkların olması da kaçınılmazdır. Bunlardan en önemlisi Kur'an kıssalarındaki hedef ile kısa hikayelerin hedefleri arasındaki farklılıktır.

Kur'an kıssalarının Kur'an-ı Kerim'de yer almasının hedefi sırf edebi bir ürün ortaya koymak veya tarihi bir takım bilgiler vermek değildir. Kur'an kıssalarının hedefleri, Kur'an-ı Kerim’in genel hedeflerinden ayrılmaz. Bunları şöyle sıralamak mümkündür.

1. Tevhit yani Allah'ın birliğine davet etmek ve İslam inancını insanların gönüllerine yerleştirmek (Abbas, 2010: 44). Tevhit inancı İslam inancının temeli olduğu için bu kavramı Kur’an-ı Kerim’in bütününde bulmak mümkündür. Bu kavram ibadet esaslarında, ahlak esaslarında yer aldığı gibi Kur'an kıssalarında da yer almaktadır.

2. Kıssaların çoğunluğu Peygamberlerin hayatları ile ilgilidir. Bu kıssalarda Peygamberlerin çektiği sıkıntılar, zorluklara karşı verdikleri mücadeleler anlatılmaktadır. Böylece inanan kişilerin inançlarından dolayı hayatta karşılaşııkları ve karşılaşacakları zorluklara karşı dayanma gücü verilmek istenmektedir (Abbas, 2010: 44).

3. Ahlak esasları Kur’an-ı Kerim’in üzerinde durduğu önemli konulardan biridir. Bu konu da kıssalarda yer almıştır. Böylece Müslümanlar kıssalar yoluyla da yüce ahlaka teşvik edilmiş, kötü ahlaka düşmekten uzak durmaları tavsiye edilmiştir. Yusuf (as) kıssasında anlatılan iffetini koruması ve ahlaksızlığa düşmemesi olumlu örnek, Karun'un malı ile gururlanarak haktan ayrılması olumsuz örnek olarak sunulmaktadır (Merami \& Arabi, 1390 h: 45).

Modern Arap Edebiyatı ürünlerinden biri olan قصة قصيرة جدا çok kısa hikaye ise toplumsal konuları hedef almaktadır. Burada dini bir kaygı yoktur. Özellikle son yüzyılda Müslümanların yaşadıkları ülkelere yapılan işgaller, saldırılar, haksızlıklar, buradaki yazarları hak, adalet, hürriyet kavramlarına yönlendirmiş ve bu konuda eserler vermeye itmiştir.

Kur'an Kıssaları ile çok kısa hikaye arasındaki ikinci fark Kur'an kıssaları yukarıda da bahsedildiği gibi gerçeklere dayanması ve vahiy ürünü olmasıdır. Çok kısa hikaye ise iki grupta değerlendirilmektedir. Çok kısa hikayelerde ya gerçek olaylara vurgu yapılır. Ya da tamamen hayal ürünüdür (Abbas, 2010: 50).

Nevadir ve çok kısa hikayeler arasındaki farka gelince. Nevadir, Arap edebiyatında çok erken bir dönemde ortaya çıkmıştır. Temel hedef az kullanılan ve anlamı tam bilinmeyen kelimelerin açıklanmasıdır. Nevadir Arap edebiyatında sadece nesir türünün bir örneği değildir. Nevadir kitaplarında şiir de yer almaktadır. 


\section{Sonuç}

Araştırmamızda çok kısa hikaye ile Eski Arap edebiyatının bir ürünü olan nevadir ve Kur'an Kıssaları arasında benzer yönler ve farklı yönler ortaya konmuştur. Bu benzerliklerden harekete ederek çok kısa hikayenin eski Arap edebiyatının bir ürünü olduğunu iddia etmek mümkün değildir.

Fakat şu hususun da gözden kaçırılmaması gerekmektedir. Toplumlar birbirinden sürekli etkilenmektedir. Teknoloji, dil, edebiyat bir anda hiçbir etki olmadan ortaya çıkan ürünler değildir. Bir yerde herhangi bir edebi ürün ortaya çıkmışsa bunun arka planında, başka toplumlardan etkilenmelerin de olması kaçınılmazdır.

Ayrıca bu edebi türle ilgili her milletin kendi geçmişinde izlerini araması olumlu bir özelliktir. Böylece her millet bu yeni türle ilgili geçmişinden bazı edebi ürünleri bulacak ve bu yeni hikâye türüne kendi kimliğini katma imkanı bulacaktır.

\section{Kaynakça}

Abbas, F. (2010). Kasasu'l-Kur'ani'l-Kerim. Amman Ürdün: Daru'n-Nefais.

Akil, M. (1999). Taraifu'l-Mudhikin mine'l-Muluki ve'ş-Şuarai ve'l-Hamka ve'l-Muğaffilin. Beyrut / Lübnan.

Akyol, E. (2006). İslam Medeniyetinin Batıya Etkileri İle İlgili Bazı Değerlendirmeler. İstem, 117-134.

Avadallah, A., \& Uylaş, S. (2010). Flkra Kültürünün Türk ve Arap Edebiyatındaki Yeri. A.Ü. Türkiyat Araştırmaları Dergisi, 147-174.

Demirayak, K. (2012). Arap Edebiyat Tarihi I Cahiliye Dönemi. Erzurum.

Durmuş, İ. (2007). Nevadir. Türkiye Diyanet Vakfi İslam Ansiklopedisi (s. 29-30). içinde İstanbul: Türkiye Diyanet Vakfi.

Ebu'l-Beka, E.-H. (tsz). el-Kulliyyat Mu'cem fi'l-Mustalahat ve'l-Furuku'l-Luğaviyye. Beyrut: Muessetu'r-Risale.

el-Batayine, C. (2011). el-Kıssatu'l-Kasira Cidden Kiraa Nakdiyye. Mecelletu't-Terbiye ve'l-İlm.

el-Ezheri, E. (2001). Tehzibu'l-Luğa. Beyrut: Daru İhyai't-Turasi'l-Arabi.

er-Rayhani, M. (2014). Hau'l-Hurriye Hamsune Kıssa Kasira. Menşuratu Vizarati's-Sekafeti'lMağribiyye.

er-Razi, Z.-D. (1999). Muhtaru's-Sihah. Beyrut - Sayda: el-Mektebetu'l-Asriyye.

ez-Zebidi, M.-H. (tsz). Tacu'l-Arus min Cevahiri'l-Kamus. Daru'l-Hidaye.

ez-Zemahşeri, E.-K. (1998). Esasu'l-Belağa. Beyrut-Lübnan: Daru'l-Kutubi'l-İlmiyye.

İbn Dureyd, E.-H. (1987). Cemheratu'l-Luğa. Beyrut: Daru'l-İlm li'l-Melayin.

Merami, C., \& Arabi, M. (1390 h.). Dirasetu'l-Kıssati'l-Kur'aniyye el-Kasira Cidden ve Anasiruha. Fasile İdahat Nakdiyye.

Muhammed, S. (tsz). en-Nevadir ve't-Taraif el-Fukaha fi'ş-Şi'ri'l-Arabi. Beyrut/Lübnan: Daru'rRatibi'l-Camii.

Şavuş, S. (2018). Teksifu'd-Dilale fi Kusus Sura mine'l-Arşif li Hasen Bartal. el-Umde fi'l-Lisaniyyat ve Tahlilu'l-Hitab, 364-374.

Şengül, İ. (2002). Kıssa. Türkiye Diyanet Vakfi İslam Ansiklopedisi (s. 498-501). içinde İstanbul: Türkiye Diyanet Vakfi. 